\title{
Nota de Apresentação
}

Integrando-se nas comemorações dos cem anos de Sophia de Mello Breyner Andresen, a se completarem em 6 de novembro de 2019, dedicamos este dossiê da Revista do Centro de Estudos Portugueses da Faculdade de Letras da Universidade Federal de Minas Gerais integralmente à obra da autora.

Contemplada com o Prêmio Camões em 1999, Sophia é uma das vozes mais importantes do século XX português e sua obra não deixou de ser convocada por autores como Jorge de Sena, Herberto Helder, Adília Lopes, e os brasileiros Murilo Mendes, Manuel Bandeira e João Cabral de Melo Neto, por exemplo. Com sua poesia recentemente republicada em edições brasileiras (além da antologia organizada pelo poeta Eucanaã Ferraz para a Companhia das Letras, sua Obra poética foi publicada em 2018 pela Tinta-da-China Brasil), é necessário voltar a interpelar sua multifacetada obra, composta de poesia, conto, literatura infantil, teatro, ensaio e tradução.

As "Artes poéticas" que a autora espalha por toda a sua obra - e que, diferentemente das da Antiguidade clássica nada têm de prescritivo, mas são uma espécie de declaração de princípios poéticos - são o tema dos ensaios de Caio Gagliardi e Erick Gontijo Costa, que abrem o dossiê. Este se dedica a estudar a associação entre poesia e pensamento na obra de Sophia, que se inscreve assim numa certa tradição moderna, enquanto Gagliardi estuda em particular a "Arte poética I", tomando a ânfora ali citada como elemento para uma aproximação com a cultura japonesa e ainda com a obra de outros autores.

Em um segundo momento, o leitor encontrará reflexões sobre os lugares em que o pensamento de Sophia aporta. É tema do artigo de Maria da Conceição Guimarães o desvelar da mitologia pessoal de Sophia, pautada por um olhar ético verticalizado sobre as coisas do mundo. Na sequência, Carlos Roberto Menezes parte de uma arguta 
leitura do conto "O homem", de Contos exemplares, para mapear a cidade moderna tal como ela é construída pela autora, sobretudo "hostil, cruel e indiferente", mas passível de ser reabilitada pela humanidade. Por sua vez, Samla Borges Canilha ocupa-se em demonstrar que a partir da obra Sophia podemos recuperar alguns dos pressupostos da poesia moderna apresentados por Hugo Friedrich, especialmente "a divisão provocada no homem pelo mundo moderno", cabendo à linguagem ensaiar a reunificação da realidade, agora tornada palavra. Logo após, Paulo Braz de Sousa, em um esforço comparativo, procura enxergar na poesia portuguesa moderna duas linhagens, uma apolínea e outra dionisíaca, apoiando-se em Nietzsche, para caracterizar as poéticas de Sophia e Herberto Helder, respectivamente. Rodrigo Denubila, por seu turno, escolhe o jardim como o lugar de interesse para adentrar a poesia da autora e nela encontrar preocupações "sobre o sentido transcendente e o ontológico do ser dos entes humanos".

O compromisso e a responsabilidade social do escritor, frequentemente associados com a poesia de Sophia, são temas dos artigos de Gabriela Silva, em coautoria com Silvia Niederauer, e Rita Barbosa de Oliveira. As duas primeiras se ocupam sobretudo de Livro sexto, de 1962, para nele escutar ecos da resistência política frente ao regime salazarista, findo em 1974. Rita Oliveira, por sua vez, vai às entrevistas concedidas por Sophia para ressaltar sua crítica social que incide sobre questões como "língua, religião, cidade, ecologia, participação, política, morte, o mal e o fazer poético".

Encerra o dossiê o artigo de Ana Catarina Pereira, centrado no documentário Sophia, de João César Monteiro, de 1969. A pesquisadora analisa as posições claramente comprometidas da poeta e do realizador para o entrelaçamento artístico de que o filme é resultado. O espaço, e sua relação com a personagem e o tipo de documentário, é o motivo central da discussão empreendida.

Na seção de resenhas, Sofia Glória de Almeida Soares apresenta as linhas gerais da antologia de poemas de Sophia intitulada Coral e outros poemas, organizada por Eucanaã Ferraz (Companhia das Letras, 2018), com destaque para a presença do mar e suas figurações, enquanto Paulo 
Revista do CESP, Belo Horizonte, v. 38, n. 60, p. 7-9, 2018

Cantalice vai aos poemas de A noite imóvel (Assírio \& Alvim, 2017, Prêmio Literário Casino da Póvoa), de Luís Quintais, para neles destacar suas imagens de ruínas, escombros, escuridão e memórias de caminhos agora incompletos, fantasmas que povoam a linguagem do poeta.

Raquel dos Santos Madanêlo Souza (UFMG)

Roberto Bezerra de Menezes (UFMG)

Sofia de Sousa Silva (UFRJ) 